\title{
Bimbingan teknis akuntansi keuangan dana desa menggunakan aplikasi Siskeudes
}

\author{
Bakhtiar Abbas ${ }^{1}$, Mahmudin A.S. ${ }^{2}$, Jusbair ${ }^{3}$, Miswar Rohansyah ${ }^{4}$ \\ ${ }^{1,2,3}$ Progra $m$ Studi Manajemen, Sekolah Tinggi Ilmu Ekonomi Enam Enam Kendari \\ ${ }^{4}$ Program Studi Akuntansi, Sekolah Tinggi Ilmu Ekonomi Enam EnamKendari
}

\begin{abstract}
Villa ge fund management has a noble mandate, which is helping the government to realize economic and social justice, but has not been able to run optimally. In addition, the education management of village fund management, especially regarding villa ge financial accounting, is very minimal. Therefore, techn ical gu id a nce is needed in solving financial management problems in village funds. Targe ts to be a chieved from the technical guidance of village financial accounting, a re: (1) Providing knowledge of village fund accounting to village officials to manage village finances. (2) Practicing village fund accounting so that villa ge officials can do it the mselv es. 3 ) Prepare the administration of village fund financial reports a ccording to the standard procedures for a ccoun tability of villa ge funds. (4) Provides a way to account for village financefunds that a re carried out quickly, precise ly, accurately and efficiently. (5) Transferring knowledge and accounting knowledge of village funds to village officials so that they can be applied to the reporting of accountability of village funds accurately and accountably. The results that have been a chieved are that the apparatus is able to arrange the financial fund s of the villa ge th ro ugh the Siskeudes application system, namely: able to input the realization of village revenue, input the data on the implementation of village finances, input the data disbursement of the Work Implementation Letter to the villa ge treasurer, make SPJ advances in a dvance payments for activities, input the rest of the remaining do wnpayments activities, input tax deposit data, input money withdrawal data from the villa ge bank account. Besides being able to print villa ge draft RPJM reports, APBDes, Cash GeneralCash Books, Village Bank B ooks and be able to prin $t$ Reports on Realization of Village Budget a nd Realization Execution
\end{abstract}

Key words: fin ancial accounting for village funds, Siskeudes

\section{PENDAhuluan}

Berlakunya Undang-Undang Nomor 6 Tahun 2014 Tentang Desa dipandang perlu adanya partisipasi dari berbagai kalangan agar pelaksanaan dari undang-undang tersebut berjalan dengan baik . Diberlakukannya undang-undang tersebut maka desa memperoleh dana yang cukup besar untuk di kelola. Dilain pihak dana desa tersebut harus dapat dipertanggungjawabkan dengan baik.

Undang-undang yang baru ditandatangani 15 Januari 2014 itu menjelaskan bahwa desa pada tahun 2015 mendapatkan kucuran dana sebesar 10\% dari APBN. Dana tersebut langsung sampai ke desa. Tetapi jumlah nominal yang diberikan kepada masing-masing desa berbeda tergantung dari geografis desa, penduduk, dan angka kematian. Alokasi APBN yang sebesar 10\%, dengan meningkatnya jumlah dana yang dialokasikan langsung ke desa ini tentunya diperlukan adanya tata kelola keuangan desa yang baik.
Pengelola keuangan desa tidak hanya membutuhkan dukungan sarana, namun yang paling penting adalah dukungan sumberdaya manusia yang memiliki kompetensi dan komitmen yang dapat diandalkan. Meskipun demikian, aparat desa yang ada pada saat ini sebagian besar memiliki tingkat pendidikan yang belum memadai terutama di bidang akuntansi. Untuk itu, maka perlu adan ya bimbingan teknis akuntansi dana desa sehingga dapat mempertangungjawabkan dengan baik dana desa yang dikelolanya.

Bimbingan teknis ini dimaksudkan untuk memberikan pemahaman kepada aparat desa dalam menyusun laporan keuangannya. Dalam pelaksanaan pengelolaan akuntansi keuangan dana desa ini dapat dikembangkan dalam bentuk aplikasi, namun disisi lain mengingat keterbatasan pengetahuan aparat desa, maka dibimbing secara manual prosedur akuntansi keuangan dana desa kemudian ditunjang dengan menggunakan aplikasi. 
Pengelolaan keuangan dana desa mendapatkan peluang untuk dapat membina aparat desa khususnya pengelola keuangan dana desa. Pengelolaan dana desa mempunyai amanah luhur, yaitu membantu pemerintah untuk mewujudkan keadilan ekonomi dan sosial, namun belum dapat berjalan secara maksimal. Disamping itu, pendidikan aparat pengelola keuangan dana desa sangat minim dalam pencatatan, sehingga dibutuhkan bimbingan teknis akuntansi. Salah satu desa yang membutuhkan adalah desa Lebo Jaya Sulawesi Tenggara.

\section{METODE YANG DIGUNAKAN}

Metode yang digunakan dalam kegiatan bimbingan teknis ini adalah: (1) Pemberian materi kepada peserta yang menyangkut cara pengelolaan akuntansi keuangan dana desa, manajemen pengelola keuangan desa, prinsip-prinsip pengelola keuangan desa dan pembuatan laporan pengelolaan keuangan dana desa. (2) Ceramah mengenai materi yang diberikan. (3) Simulasi/praktek mengoperasikan Sikeudes (mulai dari menginstal aplikasi, menginput RPJMDes, APBDes, isian parameter kegiatan, dan penatausahaan lainnya yang berhubungan dengan transaksi). (4) Dialog atau diskusi (tanya jawab) pada saat bimbingan teknis sedang berlangsung sampai selesai.

\section{PELAKSANAAN DAN HASIL KEGIATAN}

Berdasarkan pada kegiatan bimbingan teknis akuntansi keuangan dana desa maka hasil yang dicapai adalah: (1) Aparat desa mampu menginput realisasi penerimaan Desa Lebo Jaya ke dalam Penerimaan Desa pada aplikasi Siskeudes. (2) Aparat desa mampu menginput data pelaksanaan keuangan Desa Lebo Jaya ke dalam isian SPP kegiatan pada aplikasi Siskeudes. (3) Aparat desa mampu menginput data pencairan SPP ke bendahara Desa Lebo Jaya ke dalam isian pencairan SPP pada aplikasi Siskeudes. (4) Aparat desa mampu membuat SPJ uang muka panjar kegiatan ke dalam isian SPJ Kegiatan pada aplikasi Siskeudes. (5) Aparat desa mampu menginput pengembalian sisa panjar kegiatan ke bendahara desa ke dalam isian Sisa Panjar pada aplikasi Siskeudes. (6) Aparat desa mampu menginput data penyetoran pajak Desa Lebo Jaya pada aplikasi Siskeudes. (7) Aparat desa mampu menginput data pengambilan uang dari rekening Bank milik Desa Lebo Jaya ke dalam isian Mutasi Kas pada aplikasi. (8) Cetak laporan rancangan RPJM Desa Lebo Jaya Tahun 2018 s/d 2023. (9) Cetak laporan APBDes Desa Lebo Jaya tahun anggaran 2018. (10) Cetak Buku Kas Umum Tunai Desa Lebo Jaya tahun anggaran 2018. (11) Cetak Buku Bank milik Desa Lebo Jaya tahun anggaran 2018. (13) Cetak Laporan Realisasi Pelaksanaan Anggaran Pendapatan dan Belanja Desa Lebo Jaya Tahun Anggaran 2018.

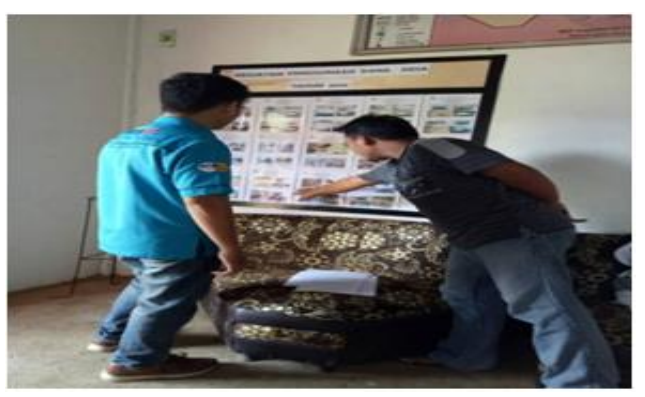

Gambar 1. Paparan penggunaan dana desa

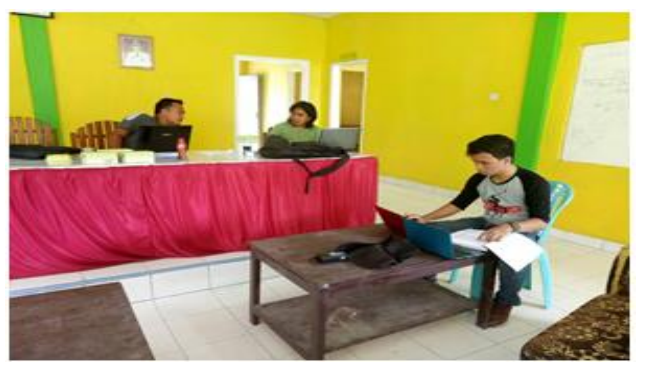

Gambar 2. Bintek penginputan data realisasi penerimaan dan pengeluaran desa menggunakan aplikasi Siskeudes

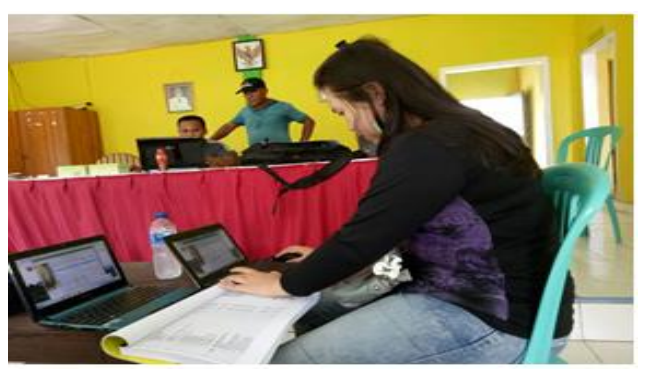

Gambar 3. Bintek penginputan data pencairan SPP menggunakan aplikasi Siskeudes 


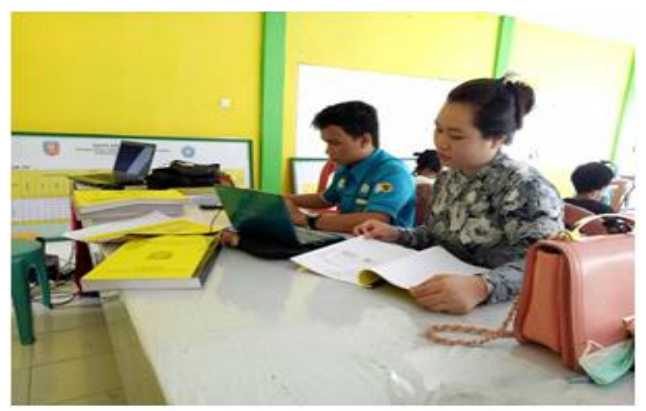

Gambar 4. Bintek penginputan data SPJ uang muka panjar dan pengembalian sisa panjar menggunakan aplikasi Siskeudes

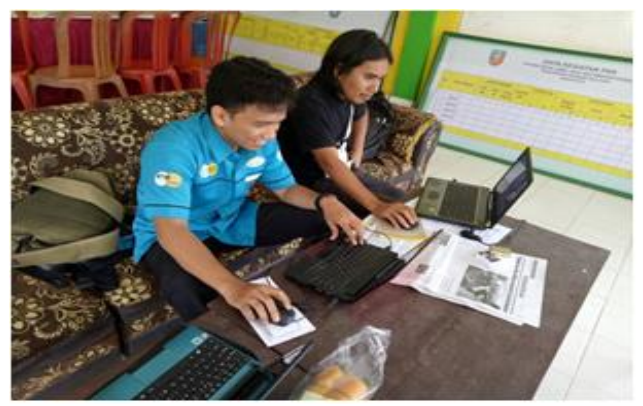

Gambar 5. Bintek penginputan data keuangan menggunakan aplikasi Siskeudes

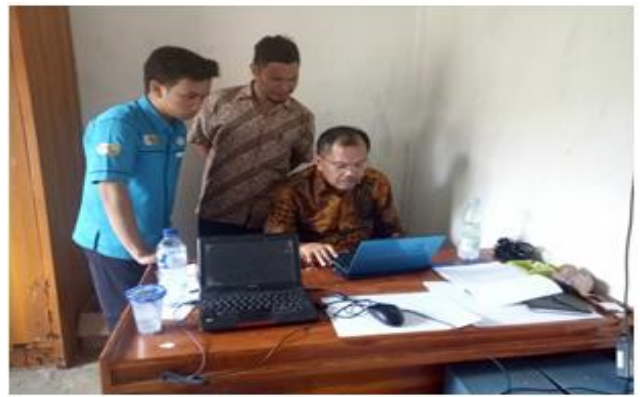

Gambar 6. Pemantauan hasil penginputan data pengambilan uang dari rekening bank milik desa

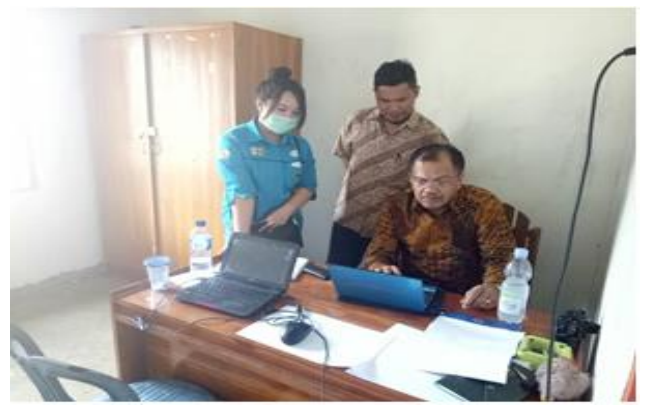

Gambar 7. Pemantauan hasil penginputan data dana secara keseluruhan dan persiapan pencetakan laporan

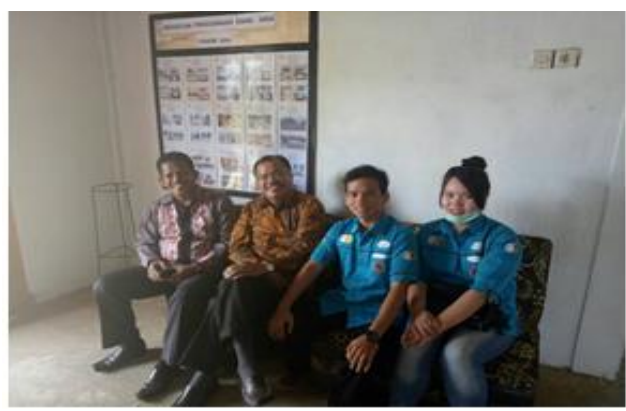

Gambar 8. Tim Pelaksana dan Pemantau Bintek dari STIE Enam Enam Kendari

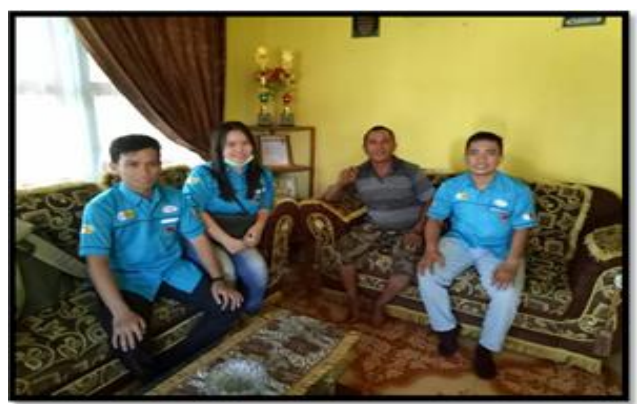

\section{KESIMPULAN}

Hasil pelaksanaan bintek akuntansi keuangan dana desa dapat ditarik kesimpulan bahwa adanya bimbingan teknik akuntansi keuangan dana desa maka aparat mampu menata keuangan dana desa melalui sistem aplikasi Siskeudes yaitu: mampu menginput realisasi penerimaan Desa, menginput data pelaksanaan keuangan Desa, menginput data pencairan SPP ke bendahara Desa, membuat SPJ uang muka panjar kegiatan, menginput pengembalian sisa panjar kegiatan, menginput data penyetoran pajak, menginput data pengambilan uang dari rekening Bank milik Desa. Disamping itu diharapakan mampu mencetak laporan rancangan RPJM Desa, APBDes, Buku Kas Umum Tunai, Buku Bank milik Desa serta mampu mencetak Laporan Realisasi Pelaksanaan Anggaran Pendapatan dan Belanja Desa. Meskipun demikian masih perlu memperhatikan kode rekening kegiatan dan kelengkapan data oleh Sekretaris desa dan pelaksana teknis kegiatan. 


\section{UCAPAN TERIMA KASIH}

Ucapan terimakasih disampaikan kepada Direktorat Jendral Pendidikan Tinggi yang telah memberikan hibah. Selanjutnya ucapan terima kasih disampaikan pula kepada Ketua Sekolah Tinggi Ilmu Ekonomi Enam Enam Kendari atas arahan dan pembinaanya selama proses kegiatan Pengabdian Masyarakat berlangsung. Demikian pula ucapan terimakasih disampaikan kepada Ketua Pusat Penelitian dan Pengabdian Masyarakat
(P3M) Sekolah Tinggi Ilmu Ekonomi Enam Enam Kendar dan Pemerintah Kabupaten Konawe, yang telah memberi fasilitas, melakukan monitoring, dan mengevaluasi kegiatan KKN-PPM hingga selesai.

\section{DAFTAR PUSTAKA}

Undang-Undang Nomor 6 Tahun 2004. 